\title{
Relevance of a crenarchaeotal subcluster related to Candidatus Nitrosopumilus maritimus to ammonia oxidation in the suboxic zone of the central Baltic Sea
}

\author{
Matthias Labrenz ${ }^{1}$, Eva Sintes ${ }^{2,3}$, Falko Toetzke ${ }^{1}$, Anita Zumsteg ${ }^{1,4}$, Gerhard J Herndl ${ }^{2,3}$, \\ Marleen Seidler ${ }^{1}$ and Klaus Jürgens ${ }^{1}$ \\ ${ }^{1}$ IOW_Leibniz Institute for Baltic Sea Research, Department of Biological Oceanography, Warnemuende, \\ Germany; ${ }^{2}$ Department of Biological Oceanography, Royal Netherlands Institute for Sea Research, Texel, The \\ Netherlands; ${ }^{3}$ Department of Marine Biology, University of Vienna, Vienna, Austria and ${ }^{4}$ Eidg. Forschungsanstalt \\ für Wald, Schnee und Landschaft WSL, Research Unit Soil Sciences, Birmensdorf, Switzerland
}

\begin{abstract}
Marine pelagic redoxclines are areas of enhanced biogeochemical cycling inhabited by distinct functional groups of prokaryotes. In this study, the diversity and abundance of archaeal and bacterial nitrifying populations throughout a pelagic redoxcline in the central Baltic Sea were examined using a suite of molecular methods. 16S rRNA/rRNA gene as well as bacterial and archaeal amoA mRNA/amoA gene fingerprints and clone libraries revealed that the putative nitrifying assemblages consisted solely of one crenarchaeotal subcluster, named GD2, which was closely related to Candidatus Nitrosopumilus maritimus. Neither distinct differences between transcriptand gene-based fingerprints nor pronounced differences in the crenarchaeotal composition throughout the whole redoxcline were detected. The abundance of this GD2 subgroup, as determined by the oligonucleotide probe Cren537 and the newly developed and more specific probe Cren679 showed that GD2 and total crenarchaeotal cell numbers were nearly identical throughout the redoxcline. The highest GD2 abundance $\left(2.3 \times 10^{5}\right.$ cells $\left.\mathrm{I}^{-1}\right)$ occurred in the suboxic zone, accounting for around $26 \%$ of total prokaryotic cells. Below the chemocline, GD2 abundance was relatively stable $\left(1.5-1.9 \times 10^{5}\right.$ cells ml $\left.{ }^{-1}\right)$. Archaeal amoA expression was detected only in the putative nitrification zone and formed a narrow band in the suboxic layer, where ammonium, oxygen, nitrate, nitrite and phosphate concentrations were below $5 \mu \mathrm{moll}^{-1}$. To our knowledge this is the first study to show the dominance of only one crenarchaeotal nitrifying key cluster in a natural habitat. The metabolic properties and survival mechanisms present in this cluster inside and outside the nitrification zone remain to be determined.
\end{abstract}

The ISME Journal (2010) 4, 1496-1508; doi:10.1038/ismej.2010.78; published online 10 June 2010

Subject Category: microbial population and community ecology

Keywords: central Baltic Sea; Crenarchaea; $a m o A$ gene; pelagic redoxcline

\section{Introduction}

The Baltic Sea is the world's second largest brackish basin. The Baltic proper comprises a number of deep areas, of which the Gotland Deep is the largest. These areas are characterized by periodically anoxic conditions in their bottom waters. A stable halocline below 50-60 $\mathrm{m}$ separates the water column into an upper oxygenated layer and an underlying oxygendeficient and anoxic/sulfidic layer (Lepland and

Correspondence: M Labrenz, Leibniz-Institut für Ostseeforschung Warnemünde (IOW), Seestrasse 15, 18119 Rostock-Warnemünde, Germany.

E-mail: matthias.labrenz@io-warnemuende.de

Received 10 February 2010; revised 3 May 2010; accepted 4 May 2010; published online 10 June 2010
Stevens, 1998; Neretin et al., 2003), resulting in a vertically stratified redoxcline that is responsible for a distinct prokaryotic stratification (Rheinheimer et al., 1989; Labrenz et al., 2007). For example, high dark $\mathrm{CO}_{2}$ fixation is consistently found in the upper sulfidic layer (Jost et al., 2010) and is driven mainly by chemolithoautotrophic Epsilonproteobacteria (Grote et al., 2008; Glaubitz et al., 2009). At the interface between nitrate and reduced sulfur compounds, Epsilonproteobacteria are also responsible for chemoautotrophic denitrification (Labrenz et al., 2005; Brettar et al., 2006), which represents probably the most important $\mathrm{N}$ loss process in the central Baltic Sea (Hannig et al., 2007). If the accordant nitrate is not laterally introduced, then it must be produced by nitrification. 
Studying the oxic-anoxic interface of the Gotland Deep from 1998 to 2000, Bauer (2003) determined mean nitrification rates of $202 \mathrm{nmol} \mathrm{NH}_{4}^{+} \mathrm{L}^{-1} \mathrm{~d}^{-1}$. In that study, based on 16S rRNA as well as bacterial ammonia monooxygenase ( $a m o A$, the key enzyme in aerobic ammonia-oxidizing bacteria) gene analyses, only Betaproteobacteria phylogenetically related to Nitrosomonas or Nitrosospira could be identified as putative nitrifying organisms. However, the highest cell numbers determined by fluorescence in situ hybridization (FISH) corresponded to only $0.6-3.9 \%$ of total prokaryotic cell counts. In fact, until recently nitrification was thought to be exclusively a bacterial feature, but an amoA-like gene has been detected on an insert in a fosmid clone library from soil also carrying a crenarchaeotal $16 \mathrm{~S}$ rRNA gene, thus demonstrating the nitrifying potential of nonthermophilic Crenarchaeota for the first time (Schleper et al., 2005; Treusch et al., 2005). In parallel, amo $A$ genes on a presumptive archaeal metagenome fragment from the Sargasso Sea study were detected (Venter et al., 2004), and later on also in the marine sponge symbiont Cenarchaeum symbiosum (Hallam et al., 2006). The only freeliving cultivated representative of the marine pelagic Crenarchaeota is still $C$. Nitrosopumilus maritimus, which is known to be able to oxidize ammonium aerobically to nitrite (Könneke et al., 2005; Martens-Habbena et al., 2009). Phylogenetically, C. N. maritimus is a member of marine group I (MGI) (Schleper et al., 2005). MGI Crenarchaeota are widely distributed throughout the mesopelagic ocean, reaching cell abundances accounting for up to $30 \%$ of the oceanic picoplankton (Massana et al., 2000; Karner et al., 2001; Church et al., 2009). While a considerable fraction of the MGI was suggested to be autotrophic (Herndl et al., 2005; Ingalls et al., 2006), MICRO-CARD-FISH (Herndl et al., 2005; Teira et al., 2006) and archaeal amo $A$ analyses (Agogué et al., 2008; De Corte et al., 2008) demonstrated that members of this group are not restricted to an autotrophic lifestyle. In any case, it is likely that non-thermophilic Crenarchaeota have a significant role in the global nitrogen cycle (Francis et al., 2005; Wuchter et al., 2006; Erguder et al., 2009).

Recently, the relevance of nitrifying Crenarchaeota and Bacteria was also shown for the suboxic zones of Black Sea redoxclines. Applying gene abundance and expression analyses, reactiondiffusion modeling, and ${ }^{15} \mathrm{~N}$ incubation experiments, Lam et al. (2007) identified ammonium-oxidizing Crenarchaeota as well as gammaproteobacterial ammonia-oxidizing bacteria as important nitrifiers and proposed that nitrification is coupled to anammox (anaerobic ammonia oxidation). 16S rRNA gene analyses by Coolen et al. (2007) identified different crenarchaeotal phylotypes throughout the Black Sea suboxic zone. The importance of nitrifying organisms, especially in the suboxic zones of Black Sea redoxclines, is also supported by biomarker analyses indicating the presence of
Crenarchaeota or nitrifying bacteria (Wakeham et al., 2007; Schubotz et al., 2009).

In principle, pelagic redoxclines of the central Baltic Sea are physicochemically comparable to those of the Black Sea, as these specific habitats share several important microbial organisms involved in the C-, $\mathrm{N}$ - and S-cycle (Labrenz et al., 2007). However, in contrast to the Black Sea, central Baltic Sea redoxclines are irregularly oxygenated after inflow events of saline- and oxygen-rich North Sea water (Reissmann et al., 2009), albeit eventually becoming re-established. Additional disturbances include small-scale turbulence, which can produce local mixing events (Lass et al., 2003). Thus, the extended suboxic zones characteristic of the Black Sea (Yakushev et al., 2008) are absent in Baltic redoxclines. Nevertheless, 16S rRNA fingerprinting analyses has indicated that MGI Crenarchaeota are also prominent in suboxic zones of the central Baltic Sea (Labrenz et al., 2007).

The main objective of this study was to assess the diversity and abundance of nitrifying assemblages throughout a central Baltic Sea redoxcline. Although $a m o A$ gene and transcript analyses failed to provide evidence of bacterial ammonium-oxidizing capacities, one highly abundant nitrifying member of the MGI Crenarchaeota was instead detected.

\section{Materials and methods}

The complete Materials \& Methods part is given as Supplementary information.

\section{Sampling}

Water samples were obtained from the central Baltic Sea onboard the RV Maria S. Merian in February 2006 (Baltic Sea monitoring station 271, Figure 1). Samples from different depths around the chemocline, defined as the uppermost presence of sulfide, were collected in free-flow bottles attached to a conductivity, temperature and depth-rosette.

Physicochemical structure of the water column Chemical profiles of oxygen, hydrogen sulfide, ammonia, phosphate, nitrite and nitrate were determined as described elsewhere (Grasshoff et al., 1983).

\section{Bacterioplankton sampling}

For catalyzed reporter deposition fluorescence in situ hybridization (CARD-FISH), $100 \mathrm{ml}$ of water samples were directly transferred to glass bottles and fixed with particle-free formaldehyde $(2 \%$ final concentration) at $4{ }^{\circ} \mathrm{C}$ for $2-5 \mathrm{~h}$. Portions of $40-45 \mathrm{ml}$ were filtered onto white polycarbonate membrane filters (Millipore GTTP, $0.2-\mu \mathrm{m}$ pore size, $47-\mathrm{mm}$ diameter, Molsheim, France), which were then rinsed with sterile seawater, air dried and stored at $-80^{\circ} \mathrm{C}$ until further processing. For nucleic acid 
1498

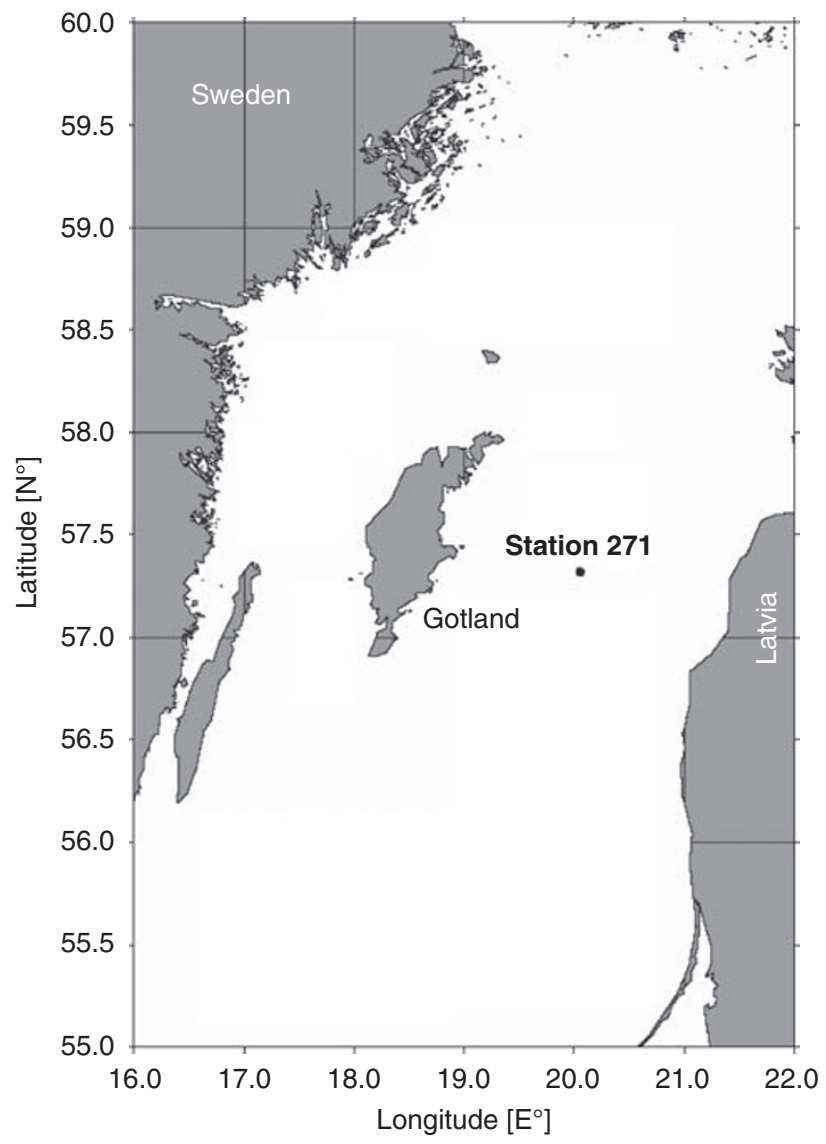

Figure 1 Map of the central Baltic Sea and position of the sampling station $271\left(57^{\circ} 19.2^{\prime} \mathrm{N} ; 20^{\circ} 03^{\prime} \mathrm{E}\right.$, Gotland Deep). extraction, water samples of 1-2 l were filtered onto white Durapore filters (Millipore GVWP, $0.22-\mu \mathrm{m}$ pore size, $47-\mathrm{mm}$ diameter) and stored frozen at $-80^{\circ} \mathrm{C}$.

\section{Nucleic acid extraction and complementary DNA (cDNA) synthesis}

RNA and DNA were extracted from filters using an acidic phenol extraction protocol (Weinbauer et al., 2002). Before RT-PCR, RNA-containing extracts were purified from DNA by incubation with DNAse I (DNA-free-Kit, Ambion, Austin, TX, USA or amplification-grade enzyme, Invitrogen Corporation, CA, USA) at $37^{\circ} \mathrm{C}$ for $30 \mathrm{~min}$ and the RNA concentrations determined using a NanoDrop ND1000 spectrophotometer (NanoDrop Technologies, Wilmington, DE, USA). To retrieve cDNA the iScript cDNA Synthesis-Kit (Bio-Rad Laboratories, Hercules, CA, USA), the Access One-Step-RT-PCR kit (Promega, Madison, WI, USA), or Superscript III First-Strand Synthesis supermix (Invitrogen) were used following the protocols of the respective manufacturer. In each reverse transcription reaction, RNA samples without or with denaturized reverse transcriptase were used as controls in the PCR.

16S rRNA/rRNA gene-based diversity analyses Single-strand conformation polymorphism (SSCP) fingerprinting. Archaeal w036/039-primers (Table 1) were used for $16 \mathrm{~S}$ rcDNA and 16S rRNA gene amplification in samples obtained from eight different depths throughout the redoxcline (Figure 2). PCR,

Table 1 Primers used in this study

\begin{tabular}{|c|c|c|c|c|}
\hline Primers & Sequence $\left(5^{\prime}-3^{\prime}\right)$ & Position & Specificity & Reference \\
\hline \multicolumn{5}{|l|}{$16 S$ rRNA } \\
\hline 1492R & GGTTACCTTGTTACGACTT & $1492 \mathrm{R}^{\mathrm{a}}$ & Universal & (Lane, 1991) \\
\hline Arch21F & TTCCGGTTGATCCYGCCGGA & $7 \mathrm{~F}^{\mathrm{a}}$ & Archaea & (DeLong, 1992) \\
\hline w036 & TCCAGGCCCTACGGGG & $333 \mathrm{~F}^{\mathrm{a}}$ & Archaea & (Leclerc et al., 2001) \\
\hline w039 & CTCCCCCGCCAATTCCT & $915 R^{a}$ & Archaea & (Leclerc et al., 2001) \\
\hline \multicolumn{5}{|l|}{ amoA } \\
\hline AOA-amoA-f & CTGAYTGGGCYTGGACATC & ND & Archaea & (Coolen et al., 2007) \\
\hline AOA-amoA-r & TTCTTCTTTGTTGCCCAGTA $^{\mathrm{c}}$ & ND & Archaea & (Coolen et al., 2007) \\
\hline Arch-amoAF & STAATGGTCTGGCTTAGACG & ND & Archaea & (Francis et al., 2005) \\
\hline Arch-amoAR & GCGGCCATCCATCTGTATGT & ND & Archaea & (Francis et al., 2005) \\
\hline Arch-amoA-for & CTGAYTGGGCYTGGACATC & ND & Archaea & (Wuchter et al., 2006) \\
\hline Arch-amoA-rev & TTCTTCTTTGTTGCCCAGTA & ND & Archaea & (Wuchter et al., 2006) \\
\hline$A m o A-1 \mathrm{~F}$ & GGGGTTTCTACTGGTGGT & $332 \mathrm{~F}^{\mathrm{d}}$ & $\beta$-proteobacteria & (Rotthauwe et al., 1997) \\
\hline$A m o A-2 \mathrm{R}$ & CCCCTCKGSAAAGCCTTCTTC & $822 \mathrm{R}^{\mathrm{d}}$ & $\beta$-proteobacteria & (Rotthauwe et al., 1997) \\
\hline amoAr NEW & CCCCTCBGSAAAVCCTTCTTC & ND & $\beta$-proteobacteria & (Hornek et al., 2006) \\
\hline$A m o A-3 \mathrm{~F}$ & GGTGAGTGGGYTAACMG & $295 \mathrm{~F}^{\mathrm{d}}$ & $\gamma$-proteobacteria & (Purkhold et al., 2000) \\
\hline$A m o B-4 \mathrm{R}$ & GCTAGCCACTTTCTGG & $44 \mathrm{R}^{\mathrm{e}}$ & $\gamma$-proteobacteria & (Purkhold et al., 2000) \\
\hline \multicolumn{5}{|c|}{ pGEM-T Easy Vector } \\
\hline SP6 & ATTTAGGTGACACTATAG & & Promoter & Promega Corporation \\
\hline T7 & TAATACGACTCACTATAGGG & & Promoter & Promega Corporation \\
\hline
\end{tabular}

${ }^{\mathrm{a}}$ Escherichia coli $16 \mathrm{~S}$ rRNA position.

'Phosporylated at the $5^{\prime}$ end of the primer.

'GC clamp (5-CGCCCGCCGCGCCCCGCGCCCGGCCCGCCGCCCCCGCCCC-3') (Muyzer et al., 1993) attached to the 5' end of the primer.

${ }^{\mathrm{d}}$ Nitrosomonas europaea amoA gene position.

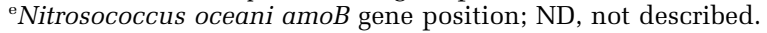




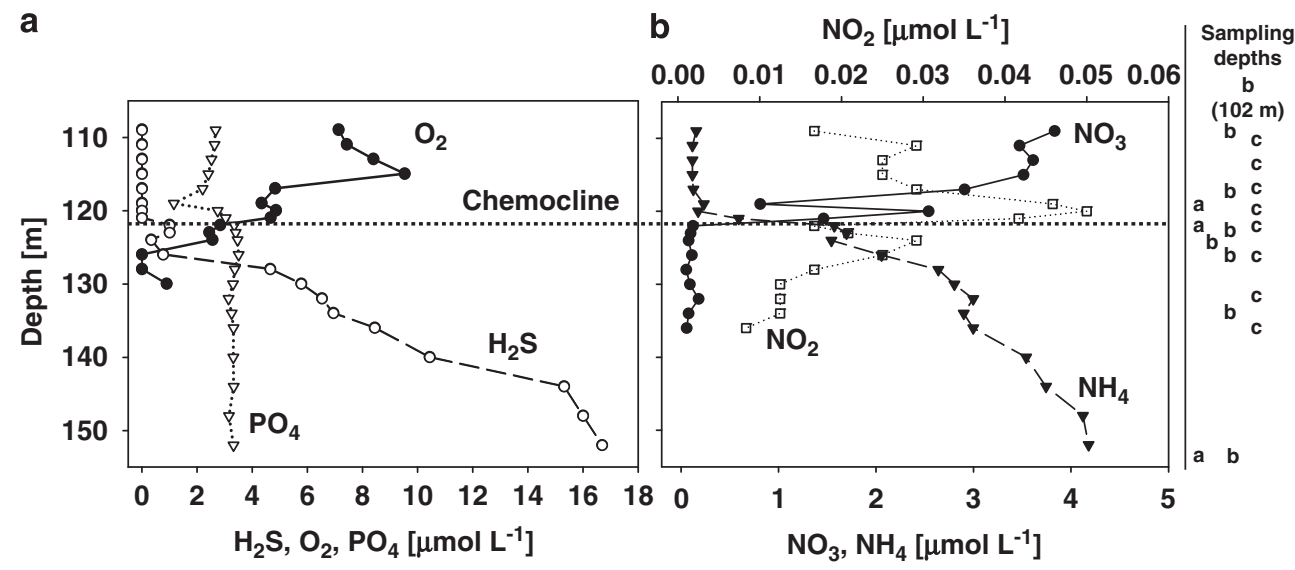

Figure 2 Depth profile throughout the water column of the Gotland Deep (station 271) in February $2006 .(\mathbf{a}) \mathrm{H}_{2} \mathrm{~S}, \mathrm{O}_{2}, \mathrm{PO}_{4}^{3-}$; (b) $\mathrm{NH}_{4}^{+}$, $\mathrm{NO}_{2}^{-}$and $\mathrm{NO}_{3}^{-}$. The dotted line denotes the chemocline. Sampling depths for molecular studies: (a) clone libraries (119, 122, 152 m); (b) SSCP fingerprinting (102, 109, 117, 122, 123, 124, 132, $152 \mathrm{~m})$; (c) DGGE fingerprinting (111, 113, 115, 119, 121, 124, 130, 134 m).

consisting of a total of 25 (cDNA) or 35 (DNA) cycles, was done following the method of Leclerc et al. (2001). Single-stranded DNA was generated and purified and SSCP analysis was carried out according to Schwieger and Tebbe (1998). Individual bands excised from the SSCP gels were re-amplified as described by Pöhler et al. (2002). PCR products were purified using the MiniElute kit (Qiagen, Hilden, Germany) according to the manufacturer's protocol and sequenced by Seqlab (Göttingen, Germany).

16S rRNA/rRNA gene clone library construction and RFLP. Archaeal 16S rRNA clone libraries were prepared from genomic DNA or RNA extracts originating from the suboxic zone, suboxic-sulfidic interface, and sulfidic zone (Figure 2). The primer systems Arch21F/1492R, w036/1492R and Arch21F/ w039 (Table 1) were used to amplify 16S rRNA for PCR, which was performed as described above. The PCR products were purified also as described above and cloned following the manufacturer's instructions using the pGEM-T-Easy Vector system (Promega) and competent E. coli JM109 cells. For restriction fragment length polymorphism (RFLP) and sequencing, the inserted fragment was PCR-amplified with the vector-specific primers T7 and SP6 (Table 1). The unpurified PCR products were digested with restriction enzymes Hin6I and MspI and documented as described previously (Bond et al., 2000). Identical RFLP patterns were grouped and representative cloned fragments sequenced by Seqlab using the primers Arch21F, w036, w069 or 1492R.

Phylogenetic analysis. 16S rRNA/rRNA gene sequences were examined for accuracy using the software SeqMan (DNAstar) and checked for chimeras using the Bellerophon program Huber et al. (2004). Phylogenetic affiliations of the partial sequences were initially estimated with the program BLAST (Altschul et al., 1990). Sequences were aligned using the ARB software package (Ludwig et al., 2004) and those with a similarity $>99 \%$ were grouped together. Basic trees were reconstructed based on related public sequences and generated clones of approximately 1300 nucleotides. These were reduced to 1284 unambiguously alignable positions using group-specific filters. An evolutionary -distance dendrogram was constructed using neighbor-joining (NJ), maximum likelihood (ML) and maximum parsimony (MP) algorithms. Partial SSCP sequences were individually imported using ARB parsimony and group-specific filters.

AmoA mRNA/amoA gene-based diversity analyses DGGE fingerprinting. Ten nanograms of DNA or 20 ng of RNA, both originating from eight different depths throughout the redoxcline, were used as template for the PCR (Figure 2). Seven of these depths were slightly different from those depths used for the 16S rRNA-based analysis, but still from the same biogeochemical zone. The method of Coolen et al. (2007) was followed, with 25 (cDNA) and 35 (DNA) cycles in the PCR together with the archaeal amoA primers ammonia-oxidizing Archaea (AOA)-amoA-f and AOA-amoA-r (Table 1). DGGE was performed according to Coolen et al. (2004), using 9\% polyacrylamide gels (ratio of acrylamide to bisacrylamide, $37.5: 1)$ submerged in $0.5 \times$ TAE buffer $\left(20 \mathrm{mmol}^{-1}\right.$ Tris, $20 \mathrm{mmol} \mathrm{l}^{-1}$ acetic acid, $0.5 \mathrm{~mol} \mathrm{l}^{-1}$ EDTA; $\mathrm{pH} 7.4$ ) at $60^{\circ} \mathrm{C}$. Individual bands excised from the DGGE gels were re-amplified using the above described amoA PCR protocol, purified using the MiniElute kit (Qiagen) as described by the manufacturer, and sequenced by Seqlab.

AmoA clone libraries. Archaeal and bacterial amoA clone libraries were prepared from extracts containing $10 \mathrm{ng}$ of genomic DNA or $20 \mathrm{ng}$ of RNA originating from the suboxic zone, suboxic-sulfidic interface and sulfidic zone (Figure 2). For PCR, the primer systems Arch-amoAF and Arch-amoAR 
(archaeal (Table 1; Francis et al., 2005)), AmoA-1F and AmoA-2R ( $\beta$-proteobacterial (Rotthauwe et al., 1997)), and $A m o A-3 \mathrm{~F}$ and $A m o B-4 \mathrm{R}$ ( $\gamma$-proteobacterial (Purkhold et al., 2000)) were used (Table 1), with a total of 25 (cDNA) or 30 (DNA) PCR cycles. Cloning and sequencing steps were done as described for the 16S rRNA procedure.

Phylogenetic analyses. The procedures were the same as those described for 16S rRNA. Phylogenetic trees were reconstructed based on sequence information from DGGE bands and clones, and related to public sequences. These were reduced to unambiguously alignable positions using group-specific filters, resulting in 166 valid characters. An evolutionary-distance dendrogram was constructed using NJ, ML and MP.

\section{Gene probe design}

Based on the above-described 16S rRNA and rRNA gene clone libraries, a probe directed against crenarchaeotal cells of the suboxic zone was designed with the PROBE_FUNCTION tool of the ARB package. Probe specificity was validated with the PROBE_MATCH tool of the ARB package, the SILVA database (Pruesse et al., 2007) and BLAST. Horseradish peroxidase (HRP)-labeled probes were synthesized by Biomers (Ulm, Germany). The specificity of the newly designed probe S-*-Cren0679-a-A-18 (Table 2), which was named according to the Oligonucleotide Probe Database nomenclature (Alm et al., 1996), was experimentally tested by whole-cell hybridization with different archaeal strains. With only one mismatch at the fourth base position of the gene probe, $C$. 'Nitrosopumilus maritimus' SCM1 served as positive control. With 9 and 7 mismatches, respectively, Halorubrum lacusprofundi (DSM5036T) and Pyrococcus furiosus (DSM3638T) served as negative controls (Table 2). All strains were cultivated following the recommendations of the DSMZ (Braunschweig, Germany).

\section{Cellular abundances}

Total cell numbers were determined by flow cytometric analyses as described previously (Labrenz et al., 2007). All HRP-labeled probes, appropriate sequences, target sites and hybridization conditions used in this study are described in Table 1 of the Supplementary information. Non-specific binding was determined using the NonEUB probe. By varying the formamide concentration, the hybridization conditions for the newly designed probe Cren679 were optimized (formamide concentrations tested: $0,15,20,25,30,35,50$ and $60 \%$ ). A concentration of $35 \%$ formamide in the hybridization buffer was found to be optimal for probe specificity.

The euryarchaeotal CARD-FISH enumeration was carried out according to the proteinase $\mathrm{K}$ protocol of
Table 2 Probe sequence, appropriate target sites and corresponding sequences in other Archaea, including reference organisms

\begin{tabular}{|c|c|c|}
\hline $\begin{array}{l}S-{ }^{*}-\text { Cren-0679-a- } A-18 \\
\text { target/reference } \\
\text { organisms }\end{array}$ & Mismatch & $\begin{array}{c}\text { Probe 3'GCCTTC } \\
\text { CTTCCCCATTTT' Target } 5 \\
\text { 'CGGAAGGAAGGGGUAAAA' }\end{array}$ \\
\hline $\begin{array}{l}\text { Uncultured Baltic } \\
\text { crenarchaeote clone } 9\end{array}$ & 0 & - \\
\hline $\begin{array}{l}\text { Uncultured Baltic } \\
\text { crenarchaeote } \\
\text { SSCP_band_4 }\end{array}$ & 0 & - - \\
\hline $\begin{array}{l}\text { Uncultured } \\
\text { crenarchaeote } \\
\text { MERTZ_2CM_56 }\end{array}$ & 0 & 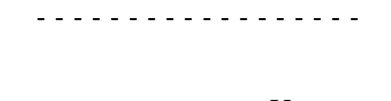 \\
\hline $\begin{array}{l}\text { Uncultured archaeon } \\
\text { CS_R008 }\end{array}$ & 1 & $-\ldots$ \\
\hline $\begin{array}{l}\text { Uncultured archaeon } \\
\text { clone BSA14-89m }\end{array}$ & 1 & $-\ldots$ U $-\ldots$ \\
\hline $\begin{array}{l}\text { 'Candidatus } \\
\text { Nitrosopumilus } \\
\text { maritimus' SCM1 }\end{array}$ & 1 & $-\ldots$ U - - - - - - - - - \\
\hline $\begin{array}{l}\text { Uncultured } \\
\text { crenarchaeote } \\
\text { MERTZ_0CM_362 }\end{array}$ & 1 & 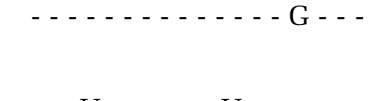 \\
\hline $\begin{array}{l}\text { Uncultured Baltic } \\
\text { crenarchaeote } \\
\text { SSCP_band_3 }\end{array}$ & 2 & - - - U - - - - - U - - - - - - \\
\hline $\begin{array}{l}\text { 'Cenarchaeūm } \\
\text { symbiosum' }\end{array}$ & 2 & - - - U - - - - - - - U - - - \\
\hline $\begin{array}{l}\text { 'Candidatus } \\
\text { Nitrosocaldus } \\
\text { yellowstonii' HL72 }\end{array}$ & 5 & $-\mathrm{C} C-\mathrm{G}--\mathrm{U}-\cdots \mathrm{U}-\cdots$ \\
\hline $\begin{array}{l}\text { Pyrococcus furiosus } \\
\left(\text { DSM } 3638^{\mathrm{T}}\right)\end{array}$ & 7 & - C C G G - - U - . - U U G - - \\
\hline $\begin{array}{l}\text { Halorubrum } \\
\text { lacusprofundi } \\
\left(\mathrm{DSM}_{5036^{\mathrm{T}}}\right)\end{array}$ & 9 & U C C G G - - U - - A - U G - - \\
\hline
\end{tabular}

The probe was named according to the Oligonucleotide Probe Database nomenclature (Alm et al., 1996) and is abbreviated in the text as Cren679.

Teira et al. (2004), but this method was not successful for the Cren537 and Cren679 gene probes. Therefore, the crenarchaeotal cell wall was permeabilized and the subsequent steps carried out as described by Sekar et al. (2003). Specifically, filter sections were washed in pre-warmed washing buffer and the tyramide signal was amplified with 5-(and 6-) carboxyfluorescein-labeled tyramides. The preparations were counterstained with a previously described mixture of $4^{\prime}, 6^{\prime}$-diamidino-2-phenylindol (DAPI), Citifluor and VectaShield (Pernthaler et al., 2002). Stained filter sections were examined with an epifluorescence microscope (Axioskop 2 mot plus, Zeiss) as described previously (Grote et al., 2007). Ratios of gene probe versus DAPI-stained cells were determined. Group-specific cell numbers were calculated by adjusting the ratios to flow cytometry-based total cell numbers.

\section{Quantification of amoA gene transcripts by real-time PCR}

Quantitative PCR (qPCR) standards were prepared as described by Agogué et al. (2008). All qPCR 
analyses were conducted on an iCycler iQ5 thermocycler (Bio-Rad). Archaeal or $\beta$-proteobacterial amo $A$ transcripts were determined in triplicate on non-diluted or 1:5 and 1:25 diluted cDNA and RNA samples. The methods of Coolen et al. (2006) and Agogué et al. (2008) were used for the qPCR, together with the primers Arch-amoA-for and Arch-amoA-rev and the primers amo $A-1 \mathrm{~F}$ and amoAr NEW (Table 1). AmoA abundance of the samples were calculated by simultaneously quantifying the standard, prepared as 10-fold serial dilutions ranging from $10^{7}$ to $10^{1}$ copies.

Nucleotide sequence accession numbers

Sequences were deposited in the GenBank database under accession numbers GU386315 to GU386337, and GU455423.

\section{Results}

Physicochemical structure of the redoxcline

The pelagic redoxcline was established from approximately $110 \mathrm{~m}$ to $130 \mathrm{~m}$. Sulfide was detectable from a depth of $122 \mathrm{~m}$ onwards and increased to $17 \mu \mathrm{mol} \mathrm{l}^{-1}$ at a depth of $150 \mathrm{~m}$ (Figures 2a and b). At the chemocline, oxygen was still detectable and was present at concentrations of $3 \mu \mathrm{moll}^{-1}$, with an overlap of $\mathrm{O}_{2}$ and $\mathrm{H}_{2} \mathrm{~S}$ at lower concentrations measurable at a depth ranging from $122 \mathrm{~m}$ to $130 \mathrm{~m}$ (Figure 2a). Phosphate concentrations were generally between 2.2 and $3.3 \mu \mathrm{moll}^{-1}$; however, at $119 \mathrm{~m}$, they dropped to $1.2 \mu \mathrm{moll}^{-1}$ (Figure 2a). Nitrate concentrations decreased sharply between 110 and $120 \mathrm{~m}$ but, together with nitrite, peaked at $122 \mathrm{~m}$. Ammonium increased strongly below $120 \mathrm{~m}$, reaching a maximum value of $4.2 \mu \mathrm{moll}^{-1}$ at $150 \mathrm{~m}$ (Figure 2b).

\section{Gene-based diversity}

Archaeal 16S rRNA/rRNA gene SSCP fingerprinting revealed 10 different and identifiable bands for the whole redoxcline. In general, neither distinct differences between 16S rRNA and 16S rRNA gene fingerprints nor pronounced differences in the archaeal composition throughout the redoxcline were detected for bands of highest relative abundance (Figure 3a; Supplementary information Figure 1A, B). Others, as SSCP bands 7 and 11 or SSCP band 5 were more pronounced in the sulfidic or in the suboxic zone, respectively. Phylogenetically, most of the SSCP bands belonged to the Euryarchaeota, with SSCP bands 1, 6, 7, 10, 11 and 12 representing a predominantly Baltic-Sea-specific cluster. SSCP bands 3 and 4 were members of the crenarchaeotal MGI and closely related to C. Nitrosopumulus maritimus, but constituting a specific phylogenetic cluster (Figure 4a).

From 16S rRNA/rRNA gene clone libraries based on different archaeal primer combinations,
91 clones were evaluated by RFLP analyses, but only one operational taxonomic unit could be detected for each of the three primer pairs. Subsequent sequencing of eight representative clones revealed that these were nearly $100 \%$ identical; thus, clone 9 was chosen as a representative sequence. Phylogenetically, clone 9 belonged to crenarchaeotal MGI, clustering with SSCP bands 3 and 4 and named Gotland Deep cluster 2 (GD2 (Figure 4a)). GD2 was 2\% distant to C. N. maritimus. Euryarchaeotal $16 \mathrm{~S}$ rRNA clones were not detected.

Archaeal amoA transcript and gene DGGE fingerprinting revealed eight distinct bands for the whole redoxcline (Figure $3 \mathrm{~b}$ ). No distinct differences between amo $A$ transcript and gene fingerprints were detected (Figure 3b). Phylogenetically, all amoA sequences were related to $C$. Nitrosopumilus, but they again formed a distinct cluster (Figure 4b). With the exception of DGGE_band_7, all generated DGGE sequences were identical on the amino acid level. Their distances to DGGE_band_7 and C. Nitrosopumilus amoA were 2 and $3 \%$ on the amino acid and 3 and $8 \%$ on the nucleic acid level, respectively.

Of the clones generated by amo $A$ transcript and gene clone libraries, 123 were evaluated by RFLP analyses, 9 OTUs identified and 31 representative clones finally sequenced. Comparable to the DGGE results, most of the clone sequences were identical or at least highly similar to each other ( $>98.5 \%)$. On the amino acid level, all amo $A$ sequences were identical, with clones 14 and 15 chosen as representative sequences. Phylogenetically, these were similarly related to $C$. Nitrosopumilus and grouped with the amoA sequences generated by DGGE fingerprinting (Figure $4 \mathrm{~b}$ ).

$\beta$ - or $\gamma$-proteobacterial amo $A$ cDNA or genes could not be amplified.

\section{Gene probe design}

The group-specific rRNA-targeting oligonucleotide probe $\mathrm{S}^{*}$-Cren-0679-a-A-18 (abbreviated as Cren679) was designed based on the eight nearly identical full-length crenarchaeotal 16S rRNA clones. Probe details and the number of mismatches with cultured organisms or related clone sequences are presented in Table 2. Cren679 was specific for all generated clones, SSCP_band_4, and, according to the SILVA database of August 2009, 44 other members of the GD2 cluster of organisms (Figure 4a). Within the target region of SSCP_band_3, two mismatches were found; however, it is unclear whether cells corresponding to SSCP_band_3 are detectable with Cren679. Despite one mismatch with $C$. N. maritimus SCM1 (Table 2), binding with this strain was recorded at all formamide concentrations tested, enabling the use of SCM1 as a positive control for the optimization procedure. Taking the $C$. N. maritimus mismatch 


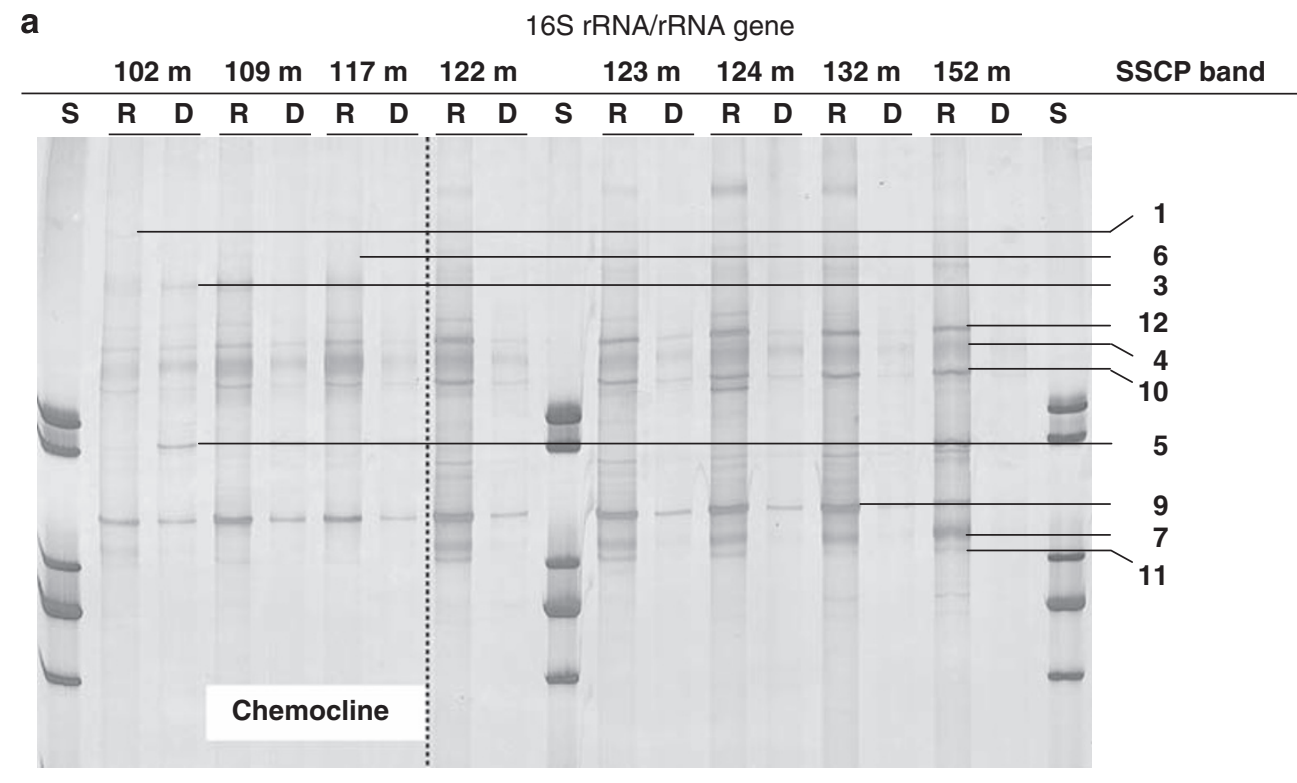

b

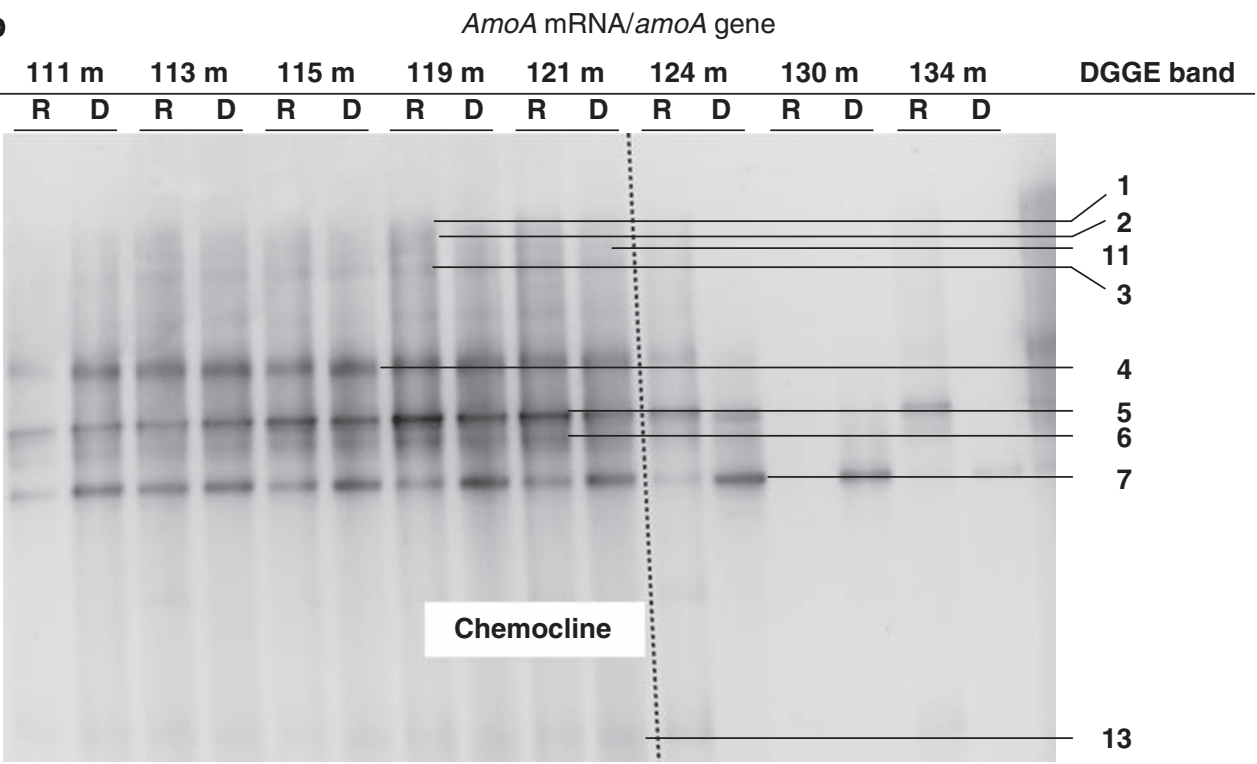

Figure 3 Genetic fingerprints of samples covering the pelagic redoxcline. Sequenced bands are labeled by numbers. The phylogenetic affiliation of these bands is presented in Figure 4a and b. (a) Archaeal 16S rRNA/rRNA gene single-strand conformation polymorphism (SSCP); (b) Crenarchaeotal amoA mRNA/amoA gene denaturing gradient gel electrophoresis (DGGE). S, standard; R, cDNA; D, DNA.

into account, gene probe Cren679 matched 838 out of 1712 MGI sequences included in the SILVA database of August 2009, but only one crenarchaeotal sequence (out of 4540) outside this group. Therefore, the specificity of gene probe Cren679 should be described as detecting members of the $C$. Nitrosopumilus and MGI cluster. In situ, cells detected by Cren679 showed a peanut-shaped cell morphology (Figure 5), similar to the morphology of $C$. N. maritimus cells (Könneke et al., 2005). The probe did not hybridize with the negative control strains Pyrococcus furiosus (DSM3638 ${ }^{\mathrm{T}}$ ) and Halorubrum lacusprofundi (DSM5036 ${ }^{\mathrm{T}}$ ).
Abundance of prokaryotes and specific groups Total prokaryotic cell numbers (TCN) varied between 0.5 and $1.3 \times 10^{6}$ cells $\mathrm{ml}^{-1}$, with the highest numbers reached below the chemocline (Figure 6a). Bacterial cell numbers followed the prokaryotic pattern, with $60-80 \%$ EUB338-positive cells below the chemocline. Total crenarchaeotal cell numbers varied between 0.8 and $2.3 \times 10^{5}$ cells $\mathrm{ml}^{-1}$, reaching highest numbers $1 \mathrm{~m}$ above the chemocline. In this zone, $25-26 \%$ of the TCN were Cren537-positive. Below the chemocline, crenarchaeotal cells remained relatively stable, with abundances of $1.5-1.9 \times 10^{5}$ cells ml $^{-1}$ that decreased 
- Uncultured Baltic archaeon SSCP_band_10 (GU386323)
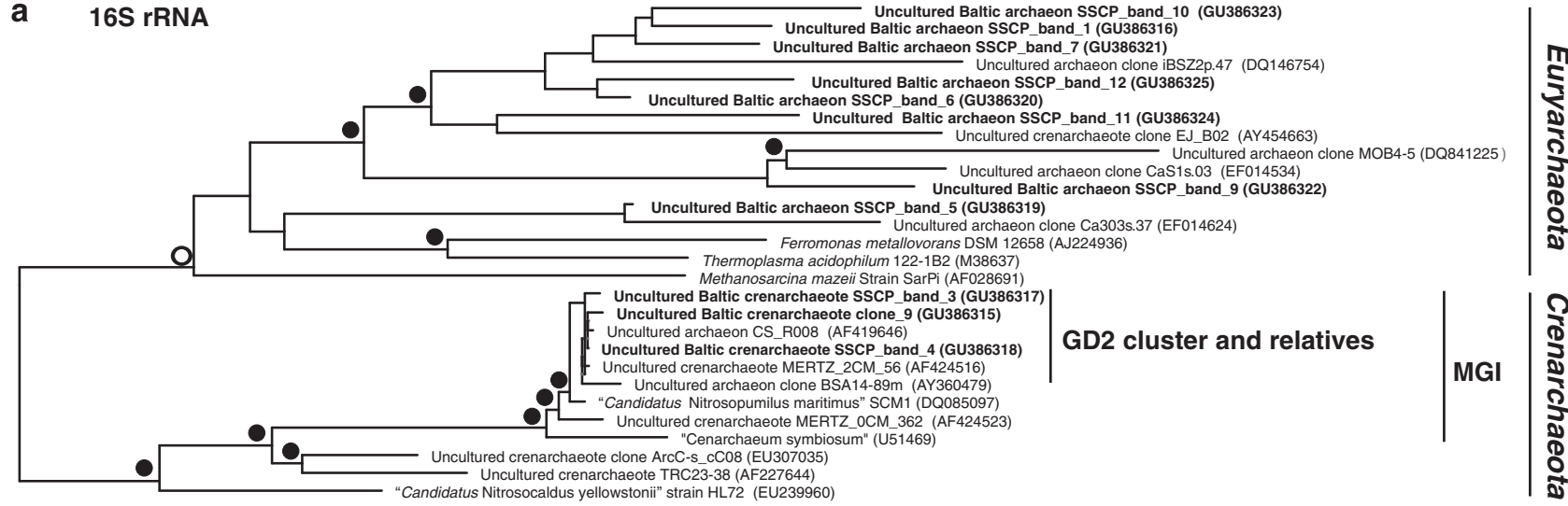

0.10

b

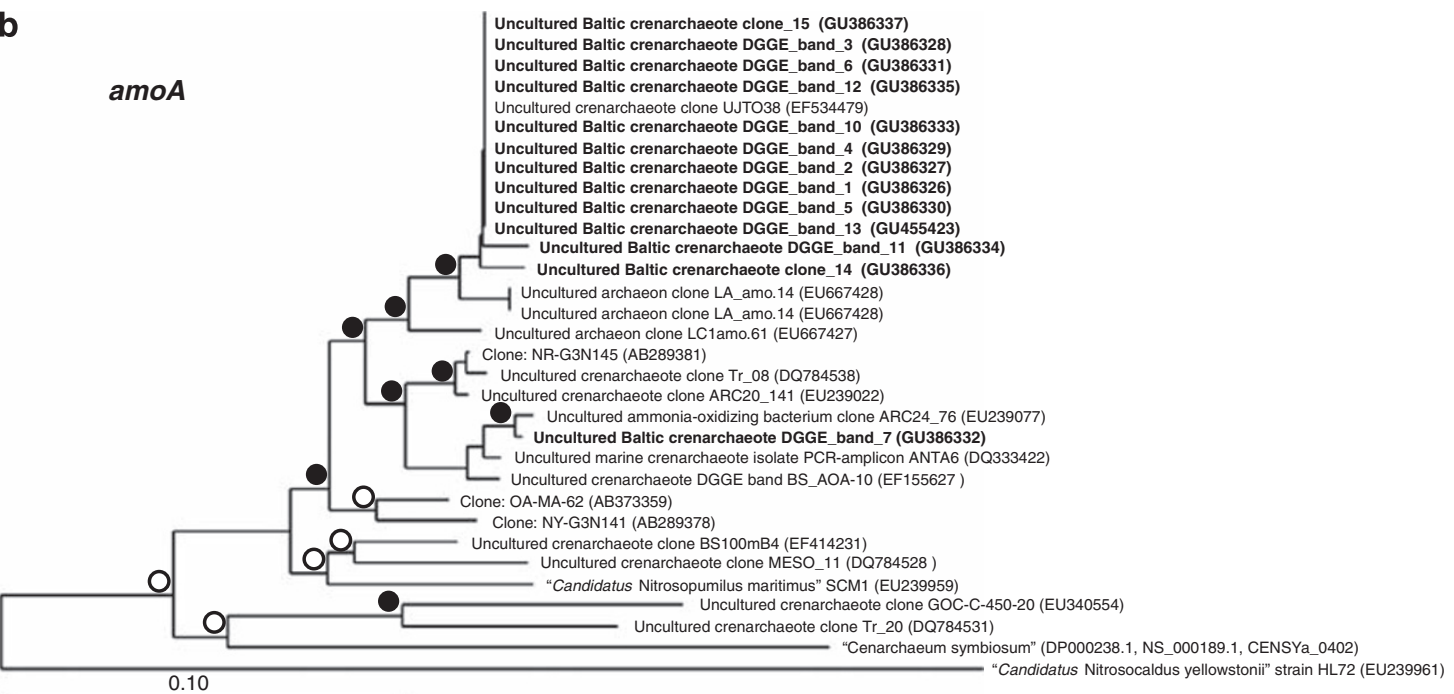

Figure 4 Phylogenetic relationships of representative sequences from the studied redoxcline samples. The evolutionary distance dendrogram was reconstructed using the Jukes-Cantor correction and NJ. Branching points supported by NJ, ML and MP algorithms are marked by a filled circle. Branching points supported by two algorithms are marked by an open circle. (a) Unrooted 16S rRNA sequencebased phylogenetic tree of members of the domain Archaea. (b) Unrooted archaeal amoA mRNA sequence-based phylogenetic tree of members of the Crenarchaeota.
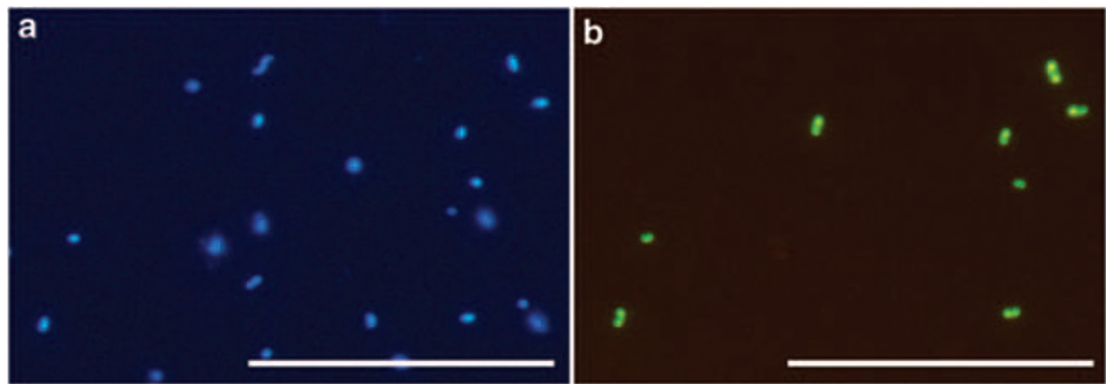

Figure 5 Photomicrographs of DAPI- or CARD-FISH-stained microorganisms from the suboxic zone of the Gotland Deep redoxcline. Bar denotes $20 \mu \mathrm{m}$. (a) DAPI-stained cells; (b) Cells from the same microscopic field stained with the gene probe Cren679 exhibit a peanut-shaped morphology.

only slightly in the deeper sulfidic zone. Above the suboxic zone, Cren537 cell numbers declined to less than $1.0 \times 10^{5}$ cells ml $^{-1}$. Cren679-positive cells closely followed the total crenarchaeotal distribution (Figure 6a). Euryarchaeota could not be detected by CARD-FISH analyses.

In a second profile of the Gotland Deep obtained in February 2006, the highest Cren679 abundance of 


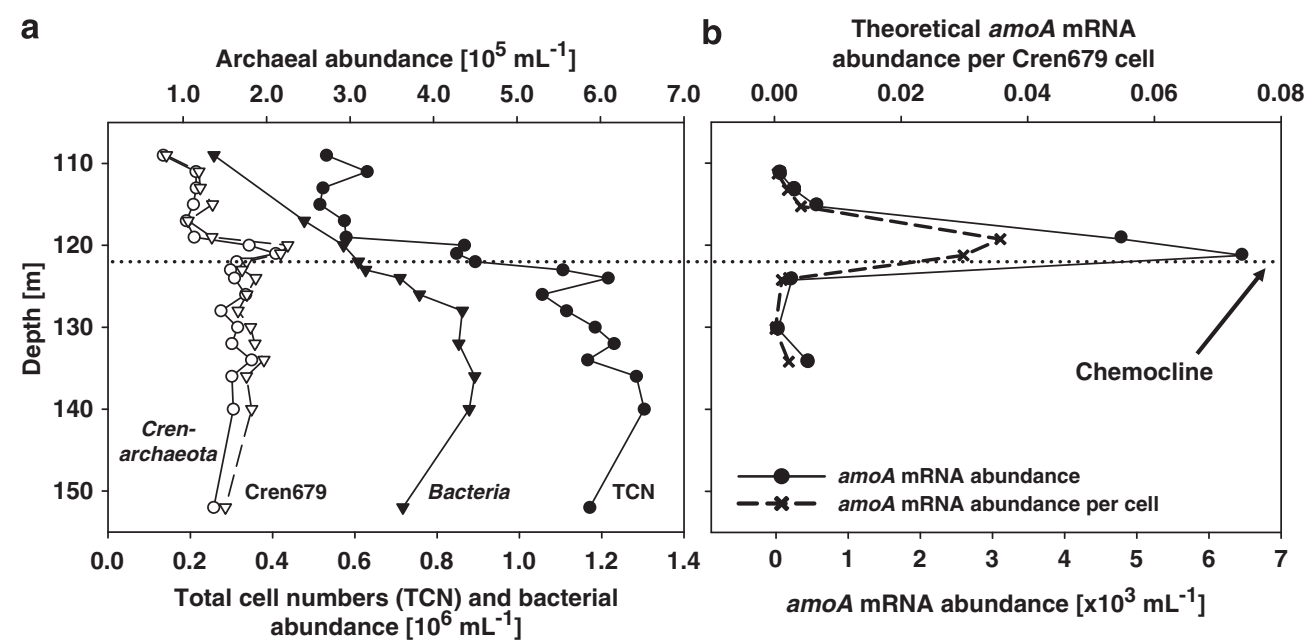

Figure 6 Prokaryotic cell numbers and amoA mRNA abundances along the Gotland Deep redoxcline in February 2006. The dashed horizontal line indicates the chemocline. (a) Vertical distribution of total cell numbers (DAPI counts), bacterial abundance, crenarchaeotal, and Cren679 abundance. (b) Vertical distribution of amoA mRNA abundances and theoretical amo $A$ mRNA abundances per Cren679 cell.

$2.1 \times 10^{5}$ cells $\mathrm{ml}^{-1}$, accounting for $26 \%$ of the TCN, was also determined in the suboxic zone, where concentrations of $4 \mu \mathrm{mol} \mathrm{O} \mathrm{I}^{-1}$ and $0.3 \mu \mathrm{mol} \mathrm{H} \mathrm{S} \mathrm{S} \mathrm{l}^{-1}$ were measured (data not shown). As in the first profile, Cren679-positive cells closely followed crenarchaeotal abundance (Cren537-positive cells) and vertical distribution, whereas Euryarchaeota were not detectable (data not shown).

\section{Quantification of amoA transcripts throughout} the redoxcline

Comparable to the $a m o A$ cloning results, no $\beta$-proteobacterial but only archaeal amo $A$ transcripts were amplifiable using RT-qPCR primer combinations. The highest number of archaeal amo $A$ transcripts $\left(6.5 \times 10^{3} \mathrm{ml}^{-1}\right)$ coincided with the highest number of Cren679-positive cells in the suboxic zone (Figures 6a and b). Calculation of the ratios of amo $A$ transcript numbers per Cren679 cell showed the highest ratios (0.04) in the suboxic zone and generally following the distribution of number of transcripts per $\mathrm{ml}^{-1}$ (Figure 6b).

\section{Discussion}

Taken together, our data set shows that not only the nitrifying community but also the crenarchaeotal assemblage itself was characterized by an astonishing low diversity (Figure 4), consisting of only one crenarchaeotal subcluster (or potentially even a single species), which we named subgroup GD2. Phylogenetically, GD2 is closely related to, but clearly separated from, $C$. Nitrosopumilus maritimus (Figure 4a). GD2 abundance was highest in the suboxic zone, where it accounted up to $26 \%$ of the total prokaryotic abundance, but relatively high cell numbers were also detected in the deeper sulfidic waters (Figure 6a). Based on maximal archaeal amo $A$ transcript abundances, archaeal ammonia oxidation occurred in a narrow suboxic zone close to the chemocline, where ammonium, oxygen, nitrate, nitrite and phosphate concentrations were below $5 \mu \mathrm{mol} \mathrm{l}^{-1}$. The observation that the crenarchaeal assemblage was almost exclusively composed of the GD2 cluster leads to the conclusion that these cells were also responsible for amo $A$ expression. This corroborates results obtained for the isolate C. N. maritimus, identified as an ammonia oxidizer (Könneke et al., 2005; Martens-Habbena et al., 2009).

\section{Archaeal diversity}

According to the results of both $16 \mathrm{~S}$ rRNA and rRNA gene SSCP fingerprinting, members of the Euryarchaeota and Crenarchaeota were present throughout the pelagic redoxcline (Figures $3 \mathrm{a}$ and 4a). Euryarchaeotal diversity was higher than that of Crenarchaeota, but summing up relative cren- and euryarchaeotal SSCP band areas as an indicator for accordant abundances, these were principally comparable throughout the redoxcline (Supplementary information Figure 1c and d). Moreover, potentially most abundant members of both phyla (SSCP bands 4 and 9) seemed to be uniformly distributed from the suboxic to the sulfidic zone, without pronounced differences between 16S rRNA and 16S rRNA gene fingerprints (Figure 3a; Supplementary information Figure 1a and b). The observed differences between eury- and crenarchaeotal diversities in the Baltic Sea might be a common phenomenon and is consistent with the findings of other studies, for instance, the lower diversity of pelagic MGI Crenarchaeota compared with Euryarchaeota described for the southern North Sea (Herfort et al., 2007). Interestingly, 
most of the euryarchaeotal sequences formed a nearly Baltic Sea-specific cluster that was at least 9\% distant from the most similar environmental $16 \mathrm{~S}$ rRNA sequence clone iBSZ2p.47 (Figure 4a). On the cellular level, Euryarchaeota were not detectable using the Eury806 gene probe. Euryarchaeotal 16S rRNA SSCP sequences were divers and showed 0-4 mismatches to gene probe Eury806. The most abundant euryarchaeotal SSCP band 9 (Figure 3a) holds 1 mismatch at the edge of the probe and should be detected, but could be below the detection limit or the cell walls not properly permeabilized by the fixation procedure. Based on the data set of this study the exact cellular euryarchaeotal abundance remains unclear; however, most recent metagenomic analyses of a comparable Baltic Sea redoxcline showed that euryarchaeotal gene abundance was below $2 \%$ of the total genes (unpublished data), supporting low euryarchaeotal abundances. This is in contrast to the redoxclines from the Black Sea and the Cariaco Trench, where both Eury- and Crenarchaeota were present in considerable numbers (Lin et al., 2006).

Only crenarchaeotal sequences were generated in the $16 \mathrm{~S}$ rRNA/rRNA gene clone libraries but they were also detected in the SSCP fingerprints. The lack of euryarchaeotal clones is probably due to the lower coverage of the primer combinations used. For instance, according to the SILVA database of August 2009 Arch21F matches only 1176 out of 10936 sequences, in comparison with 5443 matches of the w036 SSCP forward primer. All gained crenarchaeotal sequences clustered together and, with the exception of the partial sequence SSCP_band_3 (98\% sequence similarity), were $>99 \%$ similar to each other. Assuming that $16 \mathrm{~S}$ rRNA sequence similarities above 98.7-99\% indicate an affiliation with a single species (Stackebrandt and Ebers, 2006), then nearly all of the Baltic crenarchaeotal 16S rRNA sequences could have arisen from one species. Archaeal amo $A$ gene and transcript diversities supported the 16S rRNA analyses: the amo $A$ sequences were also related to $C$. Nitrosopumilus (Figure 4b) and, with the exception of DGGE band_7, all of the generated DGGE sequences were identical on the amino acid level. However, with a 16S rRNA distance of $2 \%$ and a phylogenetic separation supported by NJ, MP and ML algorithms (Figure 4a), the relationship to $C$. N. maritimus remains unexplained. Interestingly, the Baltic 16S rRNA sequences cluster together with sequences reported by Vetriani et al. (2003) (Figure 4a). Those sequences were obtained from comparable physicochemical conditions in the Black Sea, supporting recent observations that marine pelagic redoxclines share similar microbial key organisms (Labrenz et al., 2007).

Subcluster GD2 was quantified by CARD-FISH analyses. The highest cell numbers $\left(2.3 \times 10^{5}\right.$ cells $\mathrm{ml}^{-1}$ ) detected by the newly developed probe Cren679 were in the suboxic zone, accounting up to
$26 \%$ of the TCN and matching the Cren537-positive cell abundance covering most of the known Crenarchaeota (De Corte et al., 2008, Figure 6a). These results were reproduced in a second profile, in which Cren679 contributed up to $26 \%$ of the TCN. Considering the C. N. maritimus mismatch (Table 2), Cren679 matches approximately $45 \%$ of all MGI sequences included in the SILVA database of August 2009. Thus, it potentially covers different members of the MGI Crenarchaeota. Nonetheless, the results of our ribosomal, and functional gene and transcript-based diversity analyses were obtained using several primer, fingerprinting and cloning systems, all of which identified one $16 \mathrm{~S}$ rRNA and one amoA cluster, both closely related to $C$. N. maritimus (Figures 4a and b). Also, on the morphological level, the specific detection of peanut-shaped cells (Figure 5) was an indication that $C$. Nitrosopumilus relatives are targeted by probe Cren679. Hence, there is strong evidence that only subcluster GD2 was detected by both gene probes, Cren679 and Cren537 (Figure 6a). Taken together, these data point to the high likelihood that: (1) the crenarchaeotal assemblages consist only of one phylotype, named GD2, which dominates the archaeal community throughout the entire redoxcline, (2) the detected amoA gene cluster belongs to this group and, consequently, (3) GD2 is a nitrifying Crenarchaeota.

\section{Nitrification zone}

Higher nitrite concentrations combined with lower oxygen or ammonium concentrations are indicative of a nitrification zone in pelagic redoxclines. In our study, these conditions were fulfilled for a narrow zone ranging from a depth of $120 \mathrm{~m}$ to $122 \mathrm{~m}$ just above the chemocline (Figures $2 \mathrm{a}$ and $\mathrm{b}$ ). This area was designated as the nitrification zone because it contained the maximal number of archaeal amo $A$ transcripts (Figure 6b). Analogously, archaeal amoA expression in Black Sea redoxclines is confined to a narrow nitrification zone with low oxygen and ammonium concentrations and high crenarchaeotal amoA expression (Lam et al., 2007). Interestingly, the highest ratio of amoA transcript numbers per cell was in the nitrification zone (Figure 6b), but the value of 0.04 is, overall, lower than what might be expected. The rates of transcriptional regulation or amoA mRNA synthesis with respect to degradation are unknown for Cren679 cells, and absolute transcript numbers do not necessarily reflect their physiological state (Lam et al., 2007). However, we developed a new sampling device for deeper redoxcline waters, which is based on in situ fixation of water samples, and most recent analyses showed that $a m o A$ transcript numbers are approximately 20 times higher when this system is used (unpublished data). Transferring these data to our study, absolute amo $A$ transcript abundances per cell should by around 1 (assuming 100\% active cells) to $4(20 \%$ active cells) in the nitrification zone. This is in the 
range what could be expected for a population actively oxidizing ammonia.

It is not surprising that archaeal amo $A$ abundances were substantially lower in the sulfidic zone, which is inadequate for nitrification, than in the chemocline. It remains unclear, however, why the abundance of the GD2 subcluster is still high below the putative nitrification zone. This may be due to distribution processes (for example, sinking, mixing events) or to other metabolic pathways that enable a broad vertical distribution of the GD2 subgroup.

\section{Selection factors}

Despite the fact that different bacterial amoA primer systems were used (Table 1), no $\beta$ - or $\gamma$-proteobacterial amo $A$ genes or transcripts could be detected in any of the samples investigated. This finding was also supported by bacterial $16 \mathrm{~S}$ rRNA clone libraries generated from the suboxic zone, which were devoid of $\beta$ - or $\gamma$-proteobacterial nitrifiers (data not shown), and is in contrast to earlier studies of the Baltic Sea (Bauer, 2003) or the Black Sea (Lam et al., 2007), where proteobacterial ammonia oxidizers were also found in the lower oxic and suboxic zones of the pelagic redoxcline.

In our investigated redoxcline, the environmental factors favoring the dominance of the GD2 cluster are as yet unknown. Martens-Habbena et al. (2009) demonstrated that the high affinity of $C$. N. maritimus for ammonium enables it to outcompete bacterial nitrifiers at low ammonium concentrations. Therefore, the authors proposed that ammonia oxidation kinetics can determine the niche separation of nitrifying Archaea and Bacteria. In our study, the highest Cren679 cell numbers (Figure 6a) and archaeal amo $A$ abundances (Figure 6b) occurred at ammonium concentrations of less than $1 \mu \mathrm{moll}^{-1}$, which would support the assumption of Martens-Habbena et al. (2009). However, similar concentrations have been determined for the Black Sea where $\beta$ - and $\gamma$-proteobacterial nitrifiers were detected (Lam et al., 2007).

Erguder et al. (2009) reviewed the environmental factors shaping the ecological niches of AOA. These authors proposed that sulfide-containing waters favor AOA, because the inhibitory effect of sulfide or other S-containing compounds is more severe for bacterial than for archaeal nitrification. In our study, the overlap of sulfide- and oxygen-containing waters (Figure 2a), indicative of local mixing events or lateral intrusions, also supports a presumed inhibition of bacterial nitrifiers. It is known that these events are seasonally occurring in the Gotland Basin of the central Baltic Sea, but are more pronounced in fall and winter than in spring and summer (Axell, 1998). Thus, at the end of February, nitrifying GD2 could represent a sulfide-tolerating crenarchaeotal subcluster that is favored because of a longer period of sulfide pulses into the suboxic nitrification zones.

\section{Acknowledgements}

We are grateful to the captain and crew of RV 'Maria $S$. Merian'. The excellent technical assistance of Christian Meeske, Heike Brockmöller, Bärbel Buuk, and Annett Grüttmüller is greatly appreciated. Special thanks to Martin Könneke for providing cells of ' $C$. Nitrosopumilus maritimus'. ML was supported by the Deutsche Forschungsgemeinschaft (DFG), project number LA 1466/4-1,4-2, and ES, and GJH by the Dutch Science Fund (NWO-ALW), project number 835.20.023.

\section{References}

Agogué H, Brink M, Dinasquet J, Herndl GJ. (2008). Major gradients in putatively nitrifying and non-nitrifying Archaea in the deep North Atlantic. Nature 456: 788-791.

Alm EW, Oerther DB, Larsen N, Stahl DA, Raskin L. (1996). The oligonucleotide probe database. Appl Environ Microbiol 62: 3557-3559.

Altschul SF, Gish W, Miller W, Myers EW, Lipman DJ. (1990). Basic local alignment search tool. J Mol Biol 215: 403-410.

Axell LB. (1998). On the variability of Baltic Sea deepwater mixing. J Geophysical Res 103: 21667-21682.

Bauer S. (2003). Structure and function of nitrifying bacterial communities in the eastern Gotland basin (central Baltic Sea). University of Rostock, Germany.

Bond PL, Smriga SP, Banfield JF. (2000). Phylogeny of microorganisms populating a thick, subaerial, predominantly lithotrophic biofilm at an extreme acid mine drainage site. Appl Environ Microbiol 66: 3842-3849.

Brettar I, Labrenz M, Flavier S, Bötel J, Kuosa H, Christen R et al. (2006). Identification of a Thiomicrospira denitrificans-like epsilonproteobacterium as a catalyst for autotrophic denitrification in the central Baltic Sea. Appl Environ Microbiol 72: 1364-1372.

Church MJ, Wai B, Karl DM, Delong EF. (2009). Abundances of crenarchaeal amo $A$ genes and transcripts in the Pacific Ocean. Environ Microbiol: http:// dx.doi.org/10.1111/j.1462-2920.2009.02108.x.

Coolen MJL, Abbas B, van Bleijswijk J, Hopmans EC, Kuypers MMM, Wakeham SG et al. (2007). Putative ammonia-oxidizing Crenarchaeota in suboxic waters of the Black Sea: a basin-wide ecological study using $16 \mathrm{~S}$ ribosomal and functional genes and membrane lipids. Environ Microbiol 9: 1001-1016.

Coolen MJL, Hopmans EC, Rijpstra WIC, Muyzer G, Schouten S, Volkman JK et al. (2004). Evolution of the methane cycle in Ace Lake (Antarctica) during the Holocene: response of methanogens and methanotrophs to environmental change. Org Geochem 35: 1151-1167.

Coolen MJL, Muyzer G, Schouten S, Volkman JK, Sinninghe Damsté JS. (2006). Sulfur and methane cycling during the holocene in Ace Lake (Antarctica) revealed by lipid and DNA stratigraphy. In: Neretin LN (ed). Past and Present Marine Water Column Anoxia, Vol 64. Springer: Dordrecht, The Netherlands, pp. 41-65.

De Corte D, Yokokawa T, Varela MM, Agogue H, Herndl GJ. (2008). Spatial distribution of Bacteria and Archaea and $a m o A$ gene copy numbers throughout the water 
column of the Eastern Mediterranean Sea. ISME J 3: 147-158.

Delong EF. (1992). Archaea in coastal marine environments. Proc Natl Acad Sci USA 89: 5685-5689.

Erguder TH, Boon N, Wittebolle L, Marzorati M, Verstraete W. (2009). Environmental factors shaping the ecological niches of ammonia-oxidizing archaea. FEMS Microbiol Rev 33: 855-869.

Francis CA, Roberts KJ, Beman JM, Santoro AE, Oakley BB. (2005). Ubiquity and diversity of ammonia-oxidizing archaea in water columns and sediments of the ocean. Proc Natl Acad Sci USA 102: 14683-14688.

Glaubitz S, Lueders T, Abraham W-R, Jost G, Jürgens K, Labrenz M. (2009). ${ }^{13} \mathrm{C}$-isotope analyses reveal that chemolithoautotrophic Gamma- and Epsilonproteobacteria feed a microbial food web in a pelagic redoxcline of the central Baltic Sea. Environ Microbiol 11: 326-337.

Grasshoff K, Erhardt M, Kremling K. (1983). Methods of seawater analysis, Vol 2nd, Verlag Chemie Weinheim: New York

Grote J, Jost G, Labrenz M, Herndl GJ, Jürgens K. (2008). Epsilonproteobacteria represent the major portion of chemoautotrophic bacteria in sulfidic waters of pelagic redoxclines of the Baltic and Black Seas. Appl Environ Microbiol 74: 7546-7551.

Grote J, Labrenz M, Pfeiffer B, Jost G, Jürgens K. (2007). Quantitative distributions of Epsilonproteobacteria and a Sulfurimonas subgroup in pelagic redoxclines of the central Baltic Sea. Appl Environ Microbiol 73: 7155-7161.

Hallam SJ, Konstantinidis KT, Putnam N, Schleper C, Watanabe Y-i, Sugahara J et al. (2006). Genomic analysis of the uncultivated marine crenarchaeote Cenarchaeum symbiosum. Proc Natl Acad Sci USA 103: 18296-18301.

Hannig M, Lavik G, Kuypers MMM, Woebken D, MartensHabbena W, Jürgens K. (2007). Shift from denitrification to anammox after inflow events in the central Baltic Sea. Limnol Oceanogr 52: 1336-1345.

Herfort L, Schouten S, Abbas B, Veldhuis MJW, Coolen MJL, Wuchter C et al. (2007). Variations in spatial and temporal distribution of Archaea in the North Sea in relation to environmental variables. FEMS Microbiol Ecol 62: 242-257.

Herndl GJ, Reinthaler T, Teira E, van Aken H, Veth C, Pernthaler A et al. (2005). Contribution of Archaea to total prokaryotic production in the deep Atlantic Ocean. Appl Environ Microbiol 71: 2303-2309.

Hornek R, Pommerening-Röser A, Koops H-P, Farnleitner AH, Kreuzinger N, Kirschner A et al. (2006). Primers containing universal bases reduce multiple amoA gene specific DGGE band patterns when analysing the diversity of beta-ammonia oxidizers in the environment. J Microbiol Methods 66: 147-155.

Huber T, Faulkner G, Hugenholtz P. (2004). Bellerophon: a program to detect chimeric sequences in multiple sequence alignments. Bioinformatics 20: 2317-2319.

Ingalls AE, Shah SR, Hansman RL, Aluwihare LI, Santos GM, Druffel ERM et al. (2006). Quantifying archaeal community autotrophy in the mesopelagic ocean using natural radiocarbon. Proc Natl Acad Sci USA 103: 6442-6447.

Jost G, Martens-Habbena W, Pollehne F, Schnetger B, Labrenz M. (2010). Anaerobic sulfur oxidation in the absence of nitrate dominates microbial chemoautotrophy beneath the pelagic chemocline of the eastern
Gotland Basin, Baltic Sea. FEMS Microbiol Ecol 71: 226-236.

Karner MB, DeLong EF, Karl DM. (2001). Archaeal dominance in the mesopelagic zone of the Pacific Ocean. Nature 409: 507-510.

Könneke M, Bernhard AE, de la Torre JR, Walker CB, Waterbury JB, Stahl DA. (2005). Isolation of an autotrophic ammonia-oxidizing marine archaeon. Nature 437: 543-546.

Labrenz M, Jost G, Jürgens K. (2007). Distribution of abundant prokaryotic organisms in the water column of the central Baltic Sea with an oxic-anoxic interface. Aquat Microb Ecol 46: 177-190.

Labrenz M, Jost G, Pohl C, Beckmann S, Martens-Habbena W, Jürgens K. (2005). Impact of different in vitro electron donor/acceptor conditions on potential chemolithoautotrophic communities from marine pelagic redoxclines. Appl Environ Microbiol 71: 6664-6672.

Lam P, Jensen MM, Lavik G, McGinnis DF, Müller B, Schubert CJ et al. (2007). Linking crenarchaeal and bacterial nitrification to anammox in the Black Sea. Proc Natl Acad Sci USA 104: 7104-7109.

Lane DJ. (1991). 16S/23S rRNA sequencing, Vol. John Wiley and Sons: Chichester.

Lass HU, Prandke H, Liljebladh B. (2003). Dissipation in the Baltic proper during winter stratification. J Geophys Res-Oceans 108:doi:10.1029/2002JC001401.

Leclerc M, Delbes C, Moletta R, Godon J-J. (2001). Single strand conformation polymorphism monitoring of 16S rDNA Archaea during start-up of an anaerobic digester. FEMS Microbiol Ecol 34: 213-220.

Lepland A, Stevens RL. (1998). Manganese authigenesis in the Landsort Deep, Baltic Sea. Mar Geol 151: 1-25.

Lin X, Wakeham SG, Putnam IF, Astor YM, Scranton MI, Chistoserdov AY et al. (2006). Comparison of vertical distributions of prokaryotic assemblages in the anoxic Cariaco Basin and Black Sea by use of fluorescence in situ hybridization. Appl Environ Microbiol 72: 2679-2690.

Ludwig W, Strunk O, Westram R, Richter L, Meier H, Yadhukumar et al. (2004). ARB: a software environment for sequence data. Nucleic Acids Res 32: 1363-1371.

Martens-Habbena W, Berube PM, Urakawa H, de la Torre JR, Stahl DA. (2009). Ammonia oxidation kinetics determine niche separation of nitrifying Archaea and Bacteria. Nature 461: 976-979.

Massana R, DeLong EF, Pedros-Alio C. (2000). A few cosmopolitan phylotypes dominate planktonic archaeal assemblages in widely different oceanic provinces. Appl Environ Microbiol 66: 1777-1787.

Muyzer G, de Waal EC, Uitterlinden AG. (1993). Profiling of complex microbial populations by denaturing gradient gel electrophoresis analysis of polymerase chain reaction-amplified genes coding for $16 \mathrm{~S}$ rRNA. Appl Environ Microbiol 59: 695-700.

Neretin LN, Pohl C, Jost G, Leipe T, Pollehne F. (2003). Manganese cycling in the Gotland Deep, Baltic Sea. Mar Chem 82: 125-143.

Pernthaler A, Pernthaler J, Amann R. (2002). Fluorescence in situ hybridization and catalyzed reporter deposition for the identification of marine bacteria. Appl Environ Microbiol 68: 3094-3101.

Pöhler I, Wenderoth DF, Wendt-Potthoff K, Höfle MG. (2002). Bacterioplankton community structure and dynamics in enclosures during bio-remediation 
experiments in an acid mining lake. Water, Air, and Soil Poll: Focus 2: 111-121.

Pruesse E, Quast C, Knittel K, Fuchs BM, Ludwig W, Peplies J et al. (2007). SILVA: a comprehensive online resource for quality checked and aligned ribosomal RNA sequence data compatible with ARB. Nucl Acids Res 35: 7188-7196.

Purkhold U, Pommerening-Röser A, Juretschko S, Schmid MC, Koops HP, Wagner M. (2000). Phylogeny of all recognized species of ammonia oxidizers based on comparative $16 \mathrm{~S}$ rRNA and amoA sequence analysis: implications for molecular diversity surveys. Appl Environ Microbiol 66: 5368-5382.

Reissmann J, Burchard H, Feistel R, Hagen E, Lass HU, Mohrholz V et al. (2009). Vertical mixing in the Baltic Sea and consequences for eutrophication-A review. Progr Oceanogr 82: 47-80.

Rheinheimer G, Gocke K, Hoppe H-G. (1989). Vertical distribution of microbiological and hydrographicchemical parameters in different areas of the Baltic Sea. Mar Ecol Progr Ser 52: 55-70.

Rotthauwe JH, Witzel KP, Liesack W. (1997). The ammonia monooxygenase structural gene $a m o A$ as a functional marker: molecular fine-scale analysis of natural ammonia-oxidizing populations. Appl Environ Microbiol 63: 4704-4712.

Schleper C, Jurgens G, Jonuscheit M. (2005). Genomic studies of uncultivated archaea. Nature Rev Microbiol 3: 479-488.

Schubotz F, Wakeham SG, Lipp JS, Fredricks HF, Hinrichs K-U. (2009). Detection of microbial biomass by intact polar membrane lipid analysis in the water column and surface sediments of the Black Sea. Environ Microbiol 11: 2720-2734.

Schwieger F, Tebbe CC. (1998). A new approach to utilize PCR-single-strand-conformation polymorphism for 16S rRNA gene-based microbial community analysis. Appl Environ Microbiol 64: 4870-4876.

Sekar R, Pernthaler A, Pernthaler J, Warnecke F, Posch T, Amann R. (2003). An improved protocol for quantification of freshwater Actinobacteria by fluorescence in situ hybridization. Appl Environ Microbiol 69: 2928-2935.
Stackebrandt E, Ebers J. (2006). Taxonomic parameters revisited: tarnished gold standards. Microbiol Today 33: 152-155.

Teira E, Reinthaler T, Pernthaler A, Pernthaler J, Herndl GJ. (2004). Combining catalyzed reporter depositionfluorescence in situ hybridization and microautoradiography to detect substrate utilization by bacteria and archaea in the deep ocean. Appl Environ Microbiol 70: 4411-4414.

Teira E, van Aken H, Veth C, Herndl GJ. (2006). Archaeal uptake of enantiomeric amino acids in the meso- and bathypelagic waters of the North Atlantic. Limnol Oceanogr 51: 60-69.

Treusch AH, Leininger S, Kletzin A, Schuster SC, Klenk H-P, Schleper C. (2005). Novel genes for nitrite reductase and Amo-related proteins indicate a role of uncultivated mesophilic crenarchaeota in nitrogen cycling. Environ Microbiol 7: 1985-1995.

Venter JC, Remington K, Heidelberg JF, Halpern AL, Rusch D, Eisen JA et al. (2004). Environmental genome shotgun sequencing of the Sargasso Sea. Science 304: 66-74.

Vetriani C, Tran HV, Kerkhof LJ. (2003). Fingerprinting microbial assemblages from the oxic/anoxic chemocline of the Black Sea. Appl Environ Microbiol 69: 6481-6488.

Wakeham SG, Amann R, Freeman KH, Hopmans EC, Jørgensen BB, Putnam IF et al. (2007). Microbial ecology of the stratified water column of the Black Sea as revealed by a comprehensive biomarker study. Org Geochem 38: 2070-2097.

Weinbauer MG, Fritz I, Wenderoth DF, Höfle MG. (2002). Simultaneous extraction from bacterioplankton of total RNA and DNA suitable for quantitative structure and function analyses. Appl Environ Microbiol 68: 1082-1087.

Wuchter C, Abbas B, Coolen MJL, Herfort L, van Bleijswijk J, Timmers $P$ et al. (2006). Archaeal nitrification in the ocean. Proc Natl Acad Sci USA 103: 12317-12322.

Yakushev E, Chasovnikov V, Murray J, Pakhomova S, Podymov O, Stunzhas P. (2008). Vertical hydrochemical structure of the Black Sea. In: Kostianoy AG, Kosarev AN (eds). The Black Sea Environment, Vol 5Q Springer: Berlin/Heidelberg, pp. 277-307.

Supplementary Information accompanies the paper on The ISME Journal website (http://www.nature.com/ismej) 